Tersedia secara online di

Jurnal Tadris IPA Indonesia

Beranda jurnal : http://ejournal.iainponorogo.ac.id/index.php/jtii

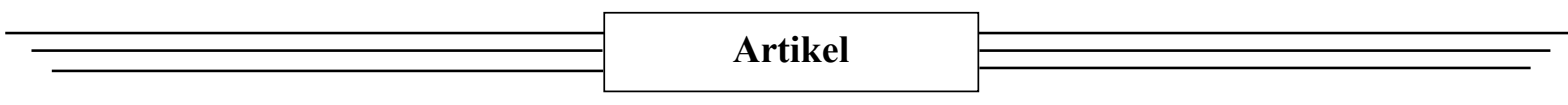

\title{
Efektivitas Penerapan Model Pembelajaran Problem Based Learning terhadap Peningkatan Keterampilan Berpikir Analitis
}

\author{
Indah Eka Nurjanah $^{1 *}$, Edi Irawan ${ }^{2}$, Rahmi Faradisya Ekapti ${ }^{3}$, Ulinnuha Nur Faizah $^{4}$ \\ 1,2,3,4 Jurusan Tadris IPA, IAIN Ponorogo, Ponorogo \\ *Corresponding Address: indahindri45@gmail.com
}

\begin{tabular}{l} 
Info Artikel \\
\hline Riwayat artikel: \\
Received: 29 Mei 2021 \\
Accepted: 9 Juli 2021 \\
Published: 26 Juli 2021 \\
\\
\hline Kata kunci: \\
Berpikir Analitis \\
Problem Based Learning \\
Pembelajaran IPA
\end{tabular}

Info Artikel

Accepted: 9 Juli 2021

Published: 26 Juli 2021

Pembelajaran IPA

\begin{abstract}
ABSTRAK
Pembelajaran IPA menuntut peserta didik untuk dapat meningkatkan kemampuan berpikir tingkat tingginya, yaitu salah satunya kemampuan berpikir secara analitis. Berpikir secara analitis menjadikan peserta didik dapat mengatasi dan juga mampu menghadapi segala permasalahan yang sedang dihadapi dengan mudah, sehingga dengan menggunakan kemampuan berpikir secara analitis peserta didik dapat memecahkan persoalan yang dihadapi. Langkah yang dapat diambil oleh guru untuk meningkatkan kemampuan berpikir secara analitis dengan menggunakan model pembelajaran yang beragam salah satunya yaitu model pembelajaran problem based learning. Penelitian ini merupakan penelitian kuantitatif dengan desain penelitian adalah quasi eksperimen. Penelitian ini termasuk pada penelitian kuantitatif komparatif karena penelitian ini bertujuan untuk membandingkan keberadaan suatu variabel atau lebih, pada dua atau lebih sampel yang berbeda, atau pada waktu yang berbeda. Prosedur penelitian ini dilakukan dengan memberikan soal pre-test dan post-test kepada peserta didik. Langkah selanjutnya hasil dari nilai pre-test dan post-test tersebut dilakukan uji dengan menggunakan uji normalitas, uji homogenitas, dan juga uji hipotesis ataupun uji t. Hasil dari nilai pre-test diuji menggunakan uji two tailed sample test, sedangkan hasil dari nilai post-test diuji menggunakan uji one tailed sample test. Tujuan dari penelitian ini adalah untuk mengetahui penggunaan model pembelajaran problem based learning efektif digunakan untuk meningkatkan kemampuan berpikir analitis peserta didik kelas VII-A MTs Ma'arif Al-Ishlah pada materi pencemaran lingkungan. Berdasarkan hasil yang diperoleh dari perhitungan SPSS dengan uji one tailed sampel test didapatkan hasil bahwa model pembelajaran problem based learning efektif digunakan untuk meningkatkan kemampuan berpikir analitis peserta didik kelas VII-A MTs Ma'arif Al-Ishlah.
\end{abstract}

(C) 2021 Indah Eka Nurjanah, Edi Irawan, Rahmi Faradisya Ekapti, Ulinnuha Nur Faizah

\section{PENDAHULUAN}

Pendidikan mempunyai peranan yang penting untuk mempersiapkan generasi penerus bangsa yang dapat berkompetisi untuk menghadapi perkembangan ilmu pengetahuan dan teknologi (Irawati \& Mahmudah, 2018). Pendidikan menjadi sorotan masyarakat khususnya di Indonesia yang ditandai dengan adanya perubahan dan pembaharuan kurikulum sehingga menyebabkan sistem pendidikan di Indonesia dalam hal kegiatan belajar mengajar menjadi lebih 
efektif dan efisien (Adi Adriadi and Nafan Tarihoran, 2016). Pemberlakuan kurikulum 2013 memberikan penegasan bahwasanya pendidikan nasional mempunyai peran sebagai salah satu sektor pembangunan nasional yang dapat dimanfaatkan sebagai upaya untuk mencerdaskan kehidupan bangsa sehingga mempunyai visi untuk mewujudkan sistem pendidikan yang dapat mengembangkan kualitas pendidikan di Indonesia (Science et al., 2013). Pembelajaran abad 21 harus mampu meningkatkan kemampuan peserta didik dalam kemampuan literacy dan numeracy. Kompetisi yang diharapkan dalam penerapan pembelajaran abad 21 dari segi tingkatan harus mampu mencapai pengetahuan pada tingkatan metakognitif (Fitriyani \& Duran Corebima, 2015).

Pembelajaran IPA dapat digunakan sebagai proses, yang dimanfaatkan untuk memecahkan suatu permasalahan yang terjadi, sebagai produk baik berupa fakta, prinsip, maupun teori dan sebagai aplikasi untuk menerapkan metode ilmiah (Risamasu, 2016). Pemberlakuan pembelajaran IPA akan memunculkan kemampuan dalam berpikir kreatif dan juga kemampuan berpikir tingkat tinggi (Rohmawati et al., 2018). Pemikiran tingkat tinggi dapat meningkatkan kemampuan peserta didik untuk mengetahui dan dapat memecahkan permasalahan yang disajikan dengan sebaik-baiknya (Rahmawati et al., 2018). Keterampilan berpikir dan memecahkan masalah merupakan kemampuan yang sangat dibutuhkan untuk menyelesaikan permasalahan kehidupan yang dapat ditemui dalam keseharian peserta didik (Noviani et al., 2017).

Kemampuan berpikir analitis merupakan kemampuan peserta didik dalam mengelompokkan beberapa bagian kemudian mencari hubungan keterkaitan dari beberapa kelompok tersebut dan menghubungkan bagian yang memiliki keterkaitan dengan fenomenafenomena dalam kehidupan sehari-hari (Fitriani et al., 2021). Kemampuan berpikir analitis meliputi kemampuan belajar untuk dapat menemukan sebuah informasi penting (membedakan), menentukan cara untuk mengetahui berbagai informasi (mengorganisasikan) dan juga menentukan sebuah tujuan. Berdasarkan pengertian diatas didapatkan kesimpulan bahwa kemampuan analisis dibagi menjadi 3 yaitu membedakan, mengorganisasikan, dan juga menentukan tujuan (Hasyim, 2018). Kemampuan berpikir secara analitis terdapat tiga indikator diantaranya yaitu (Astriani et al., 2018):

1. Membedakan, tahap ini peserta didik diharapkan mampu membedakan permasalahan penting dan juga mampu membedakan permasalahan yang relevan.

2. Mengorganisasikan, tahap ini peserta didik diharapkan mampu membedakan permasalahan yang relevan kemudian dapat mengelompokkan permasalahan secara rinci.

3. Mengatribusikan, tahap ini peserta didik diharapkan dapat mengaitkan antara permasalahan yang satu dengan permasalahan yang lainnya kemudian dapat menarik sebuah kesimpulan.

Kemampuan berpikir secara analitis ini perlu dimiliki oleh peserta didik, karena dengan menggunakan kemampuan berpikir secara analitis peserta didik akan mampu menyelesaikan permasalahan-permasalahan yang disajikan oleh guru. Kemampuan berpikir analitis akan merangsang peserta didik untuk meneliti kemudian peserta didik mengambil kesimpulan terhadap permasalahan yang diberikan oleh guru. Model pembelajaran $P B L$ dalam penerapan proses pembelajaran yang berlangsung guru terlebih dahulu memberikan permasalahan kepada peserta didik sebelum dilakukan proses pembelajaran sehingga model $P B L$ cocok dan dapat digunakan untuk meningkatkan kemampuan berpikir analitis peserta didik (Maghfiroh, 2011).

Langkah yang dapat diambil untuk dapat meningkatkan kemampuan berpikir secara analitis yaitu dengan menggunakan model pembelajaran yang sesuai salah satunya model pembelajaran yang dapat digunakan untuk meningkatkan kemampuan berpikir secara analitis yaitu dengan menggunakan model pembelajaran problem based learning. Model pembelajaran adalah alat atau prosedur yang dapat digunakan sebagai pedoman untuk tercapainya sebuah tujuan pembelajaran, di dalam model pembelajaran ini terdapat strategi, teknik, metode, bahan, media dan juga alat yang dapat digunakan sebagai penilaian pembelajaran (Afandi et al., 2013). Pembelajaran berbasis masalah ini berkaitan dengan kehidupan yang nyata (Dasar et al., 2012). 
Problem based learning adalah suatu metode pembelajaran yang dapat mengaitkan masalah yang ada dalam kehidupan sehari-hari menjadi suatu topik bagi peserta didik yang dapat dijadikan sebagai sarana belajar memecahkan masalah-masalah yang diberikan untuk dapat meningkatkan kemampuan berpikirnya (Sulastri \& Pertiwi, 2020). Permasalahan yang diberikan ini dapat digunakan untuk mengikat rasa ingin tahu peserta didik mengenai pembelajaran yang dimaksud (Adi Adriadi and Nafan Tarihoran, 2016).

Pembelajaran dengan model problem based learning adalah pendekatan pengajaran yang dapat memberikan tantangan kepada siswa untuk dapat mencari solusi dari permasalahan dunia nyata baik secara individu maupun secara kelompok. Pembelajaran dengan model problem based learning didasarkan pada prinsip bahwa masalah dapat digunakan sebagai titik awal untuk mendapatkan ilmu baru. Masalah yang disajikan dalam pembelajaran diharapkan dapat meningkatkan motivasi siswa dalam memahami konsep yang diberikan(Yusri, 2018).

Saat ini banyak penelitian tentang judul "pengaruh model pembelajaran problem based learning terhadap kemampuan pemecahan masalah". (Yusri, 2018) menjelaskan bahwa terdapat pengaruh yang signifikan setelah diterapkannya model pembelajaran problem based learning terhadap kemampuan memecahkan masalah siswa. Penelitiannya bagus dalam hal meningkatkan kemampuan siswa untuk memecahkan masalah. (Kern, 1990) mengatakan bahwa model pembelajaran berbasis masalah (problem based learning) juga berpengaruh terhadap pemahaman konsep siswa. Hal ini dapat diketahui dari hasil nilai signifikansinya $0,00<0,05$.

Kemampuan berpikir secara analitis secara analitis merupakan bagian penting dalam proses pembelajaran dan perlu dikembangkan agar peserta didik dapat memecahkan persoalan yang sedang dihadapi. Diterapkannya kemampuan berpikir secara analitis peserta didik akan dengan mudah dapat membedakan, mengorganisasikan, dan mengatribusikan masalah yang diberikan. Kenyataannya yang ditemui banyak peserta didik yang masih belum mampu meningkatkan kemampuan berpikir secara analitis. Berdasarkan penjelasan tersebut penting dilakukannya penelitian ini yang dapat digunakan untuk meningkatkan kemampuan berpikir secara analitis peserta didik kelas VII-A MTs Ma'arif Al-Ishlah pada pelajaran IPA. Tujuan dari penelitian ini adalah model pembelajaran problem based learning efektif digunakan untuk meningkatkan kemampuan berpikir analitis peserta didik MTs Ma'arif Al-Ishlah pada mata pelajaran IPA pada tema pencemaran lingkungan.

\section{METODE}

Metode penelitian yang digunakan adalah penelitian kuantitatif dengan desain penelitian yang digunakan adalah quasi eksperimen. Penelitian kuantitatif hipotesis penelitian dianggap mempunyai peranan yang penting, sehingga sebelum terjun ke lapangan hendaknya merumuskan hipotesis penelitian yang akan dilakukan (ahmadriswan nasution, 2020). Variabel pada penelitian ini dapat diukur dengan menggunakan instrument penelitian berupa tes soal dalam bentuk pilihan ganda yang dijadikan sebagai pre-test dan post-test. Penelitian ini dilakukan di MTs Ma'arif Al-Ishlah dengan menggunakan dua kelas yang dipilih secara random untuk dijadikan sebagai kelas eksperimen dan kelas kontrol. Kelas eksperimen menggunakan kelas VII-A yang diberikan perlakuan berupa model pembelajaran problem based learning berbantuan media kahoot, sedangkan kelas kontrol menggunakan kelas VII-B dengan tanpa diberikan perlakuan dan hanya menggunakan model pembelajaran konvensional atau ceramah.

Penelitian ini menggunakan instrumen pengumpulan data berupa soal pilihan ganda yang dijadikan sebagai tes pre-test yang digunakan sebagai langkah awal untuk mengetahui kemampuan berpikir analitis peserta didik kelas eksperimen dan kontrol sebelum diberikan perlakuan berupa model pembelajaran problem based learning berbantuan media kahoot untuk kelas eksperimen dan model pembelajaran konvensional atau ceramah untuk kelas kontrol. Langkah selanjutnya setelah dilakukan pre-test maka memberikan perlakuan model pembelajaran problem based learning berbantuan media kahoot untuk kelas eksperimen dan model pembelajaran konvensional atau ceramah untuk kelas kontrol. Langkah yang dapat

Jurnal Tadris IPA Indonesia Volume 1 Number 2, 2021 | p-ISSN 2776-3625 | e-ISSN 2776-3617 Copyright (C) 2021 Indah Eka Nurjanah, Edi Irawan, Rahmi Faradisya Ekapti, Ulinnuha Nur Faizah 
dilakukan setelah memberikan perlakuan berupa model pembelajaran yang telah ditentukan untuk mengetahui apakah model pembelajaran problem based learning berbantuan media kahoot efektif digunakan untuk meningkatkan kemampuan berpikir analitis peserta didik MTs Ma'arif Al-Ishlah dilakukan post-test.

Instrumen penelitian sebelum digunakan untuk penelitian telah diuji validitas dan reliabilitas terlebih dahulu dengan menggunakan aplikasi SPSS. Instrumen penelitian setelah dikatakan valid dan reliabel dilanjutkan dengan uji prasyarat yaitu uji normalitas untuk mengetahui data tersebut berasal dari populasi berdistribusi normal atau tidak normal. Penelitian ini menggunakan uji normalitas kolmogorov-smirnov dengan menggunakan SPSS (Statistic Package For Social Sciences) versi 22. Uji kolmogorov-smirnov yaitu memeriksa distribusi frekuensi sampel berdasarkan distribusi normal pada data tunggal atau data frekuensi tunggal (Rusydi Ananda, 2018). Pedoman dalam pengambilan keputusan penelitian adalah apabila nilai signifikan $<0,05$ maka berdistribusi tidak normal, sebaliknya apabila nilai signifikan $>0,05$ maka berdistribusi normal (Herawati, 2016). Selain diuji menggunakan uji normalitas data tersebut telah diuji homogenitas untuk mengetahui data tersebut berasal dari populasi berdistribusi homogen atau tidak homogen. Penelitian ini untuk menguji homogenitas dapat diperoleh dengan uji homogenitas Anova (Analysis of Variance) dengan menggunakan (Statistic package for Social Sciences) versi 22. Pengujian ini dilakukan menggunakan Uji Levene's. Kriteria dalam pengambilan keputusannya adalah apabila nilai signifikan $>0,05$ maka $\mathrm{H}_{0}$ yang diterima berarti data yang diperoleh adalah homogen, dan sebaliknya apabila nilai signifikan < 0,05 maka $\mathrm{H}_{1}$ ditolak (Nuryadi et al., 2017).

Data tersebut setelah dikatakan normal dan homogen dilanjutkan dengan melakukan uji hipotesis yaitu dengan menggunakan SPSS. Uji hipotesis bertujuan untuk mengetahui apakah model pembelajaran problem based learning berbantuan media kahoot efektif digunakan untuk meningkatkan kemampuan berpikir analitis peserta didik (Herawati, 2016). Uji hipotesis yang digunakan adalah dengan uji two tailed sample test yang digunakan untuk uji hipotesis hasil dari pre-test dan uji one tailed sample test yang digunakan untuk uji hipotesis hasil dari post-test. Hipotesis nol diterima apabila nilai dari signifikansi $>\alpha(0,05)$ (Edi Irawan, 2014).

\section{HASIL DAN PEMBAHASAN}

Berdasarkan hasil penelitian yang dilakukan di kelas VII MTs Ma'arif Al-Ishlah didapatkan hasil penelitian yang dilakukan soal-soal yang telah dibuat berdasarkan indikator yang telah ditentukan tersebut diuji validitas terlebih dahulu. Berdasarkan hasil dari uji validitas tersebut dapat diketahui bahwa dari 25 soal yang telah disebarkan kepada 34 responden ada 4 soal yang dinyatakan tidak valid. Soal tersebut tidak valid karena nilai pearson correlation nya negatif dan nilai signifikansinya lebih dari 0,05 . Pemaparan dari data tersebut dapat disimpulkan dari 25 soal tersebut hanya ada 21 soal yang dinyatakan valid dan layak untuk dijadikan soal pretest dan post test penelitian. Sebanyak 21 soal tersebut dinyatakan valid karena nilai pearson correlation nya positif dan nilai signifikansi nya kurang dari 0,05 . Soal yang telah dinyatakan valid dapat digunakan sebagai instrumen penelitian sebagai soal pre-test dan soal post-test. Selanjutnya setelah dilakukan uji validitas langkah selanjutnya yaitu melakukan uji reliabilitas dengan hasil sebagai berikut:

Tabel 1. Hasil uji reliabilitas

\begin{tabular}{cc}
\hline Cronbach'S Aplha & N of items \\
\hline .840 & 21 \\
\hline
\end{tabular}

Berdasarkan hasil dari uji reliabilitas instrumen dari 21 soal yang telah dinyatakan valid tersebut dapat diketahui bahwa semua soal tersebut dinyatakan reliabel karena nilai dari Cronbach's alpha lebih dari 0,6.

Langkah selanjutnya yang dilakukan setelah melakukan uji validitas dan uji reliabilitas melakukan uji prasyarat yaitu uji normalitas dan uji homogenitas sebelum diberikan perlakuan berupa model pembelajaran problem based learning dan model pembelajaran konvensional 
untuk mengetahui kemampuan peserta didik sebelum diberikan perlakuan berupa model pembelajaran yang digunakan berikut adalah hasil uji normalitas dan uji homogenitas soal pretest adalah sebagai berikut:

Tabel 2. Hasil uji normalitas pre-test

\begin{tabular}{|c|c|c|c|c|c|c|c|}
\hline & \multirow[b]{2}{*}{ Kelas } & \multicolumn{3}{|c|}{ Kolmogorov-Smirnov ${ }^{a}$} & \multicolumn{3}{|c|}{ Shapiro-Wilk } \\
\hline & & Statistic & df & Sig. & Statistic & df & Sig. \\
\hline \multirow[t]{2}{*}{ Nilai Peserta Didik } & Pre Test Eksperimen & 168 & 17 & $.200^{*}$ & .908 & 17 & .092 \\
\hline & Pre Test Kontrol & 184 & 17 & .130 & .901 & 17 & .071 \\
\hline
\end{tabular}

Berdasarkan data dari hasil uji normalitas pada tabel 2 di atas dapat disimpulkan bahwa nilai signifikansi pre-test pada kelas eksperimen sebesar 0,200 dan pada kelas kontrol sebesar 0,130 sehingga dari hasil tersebut dapat diketahui bahwasanya hasil dari uji normalitas kelas eksperimen dan kontrol lebih besar dari 0,05 maka dapat diambil kesimpulan bahwasanya hasil uji normalitas data pre-test pada kelas eksperimen dan kelas kontrol tersebut berdistribusi normal.

Selanjutnya setelah dilakukan uji normalitas dilakukan uji homogenitas terlebih dahulu dengan hasil sebagai berikut:

Tabel 3. Hasil uji homogenitas pre-test

\begin{tabular}{|c|c|c|c|c|c|}
\hline & & $\begin{array}{l}\text { Levene } \\
\text { Statistic }\end{array}$ & df1 & df2 & Sig. \\
\hline \multirow[t]{4}{*}{ Nilai Peserta Didik } & Based on Mean & 3.300 & 1 & 32 & .079 \\
\hline & Based on Median & 3.489 & 1 & 32 & .071 \\
\hline & $\begin{array}{l}\text { Based on Median and } \\
\text { with adjusted df }\end{array}$ & 3.489 & 1 & 21.712 & .075 \\
\hline & Based on trimmed mean & 3.747 & 1 & 32 & .062 \\
\hline
\end{tabular}

Berdasarkan data pada tabel 3 di atas dari hasil uji homogenitas dapat diketahui bahwa nilai signifikansi pre-test pada kelas eksperimen dan kelas kontrol sebesar 0,079 Sehingga dapat diketahui bahwa nilai signifikansi kelas eksperimen dan kelas kontrol tersebut lebih besar dari 0,05 sehingga dapat diambil kesimpulan bahwa data pre-test dari kedua kelas baik kelas eksperimen maupun kelas kontrol tersebut homogen.

Selanjutnya setelah melakukan uji homogenitas langkah selanjutnya melakukan uji hipotesis dengan menggunakan uji two tailed sample test dengan hasil sebagai berikut:

Tabel 4. Hasil uji hipotesis pre-test

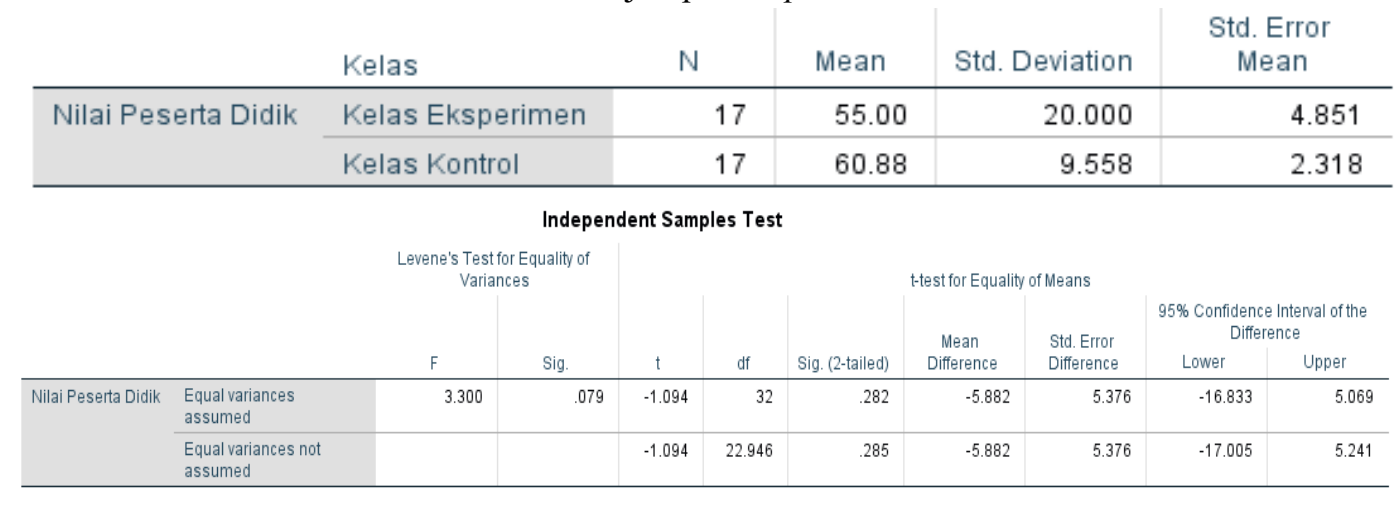

Berdasarkan dari hasil perhitungan menggunakan aplikasi SPSS pada tabel 4 diatas dapat disimpulkan bahwa dapat diketahui nilai p-value sebesar 0,282 sehingga karena p-value hasil perhitungan data tersebut lebih dari 0,05 maka $H o$ diterima. Hal tersebut mengakibatkan kemampuan berpikir analitis antara kelas eksperimen maupun kelas kontrol sebelum adanya 
perlakuan dengan menggunakan model pembelajaran problem based learning berbantuan media kahoot pada kelas eksperimen dan tanpa diberikan perlakuan apapun pada kelas kontrol dapat disimpulkan sama baiknya. Didapatkan hasil bahwa kemampuan berpikir analitis pada kedua kelas tersebut sama baiknya, maka harus digunakan uji lanjutan untuk mengetahui lebih baik mana kemampuan berpikir analitis peserta didik di antara kedua kelas tersebut, sehingga perlu dilanjutkan dengan menggunakan uji-t (one-tailed).

Langkah selanjutnya setelah melakukan uji prasyarat dan uji hipotesis sebelum diberikan perlakuan berupa model pembelajaran problem based learning berbantuan media kahoot yang digunakan pada kelas eksperimen dan model pembelajaran konvensional atau ceramah untuk kelas kontrol selanjutnya melakukan uji prasyarat dan uji hipotesis untuk soal yang telah diberikan perlakuan berupa model pembelajaran problem based learning berbantuan media kahoot yang digunakan pada kelas eksperimen dan model pembelajaran konvensional atau ceramah untuk kelas kontrol hasil dari uji tersebut dapat dilihat pada penjelasan berikut ini:

Tabel 5. Hasil Normalitas Post-test

\begin{tabular}{|c|c|c|c|c|c|c|c|}
\hline & \multirow[b]{2}{*}{ Kelas } & \multicolumn{3}{|c|}{ Kolmogorov-Smirnov ${ }^{a}$} & \multicolumn{3}{|c|}{ Shapiro-Wilk } \\
\hline & & Statistic & df & Sig. & Statistic & df & Sig. \\
\hline \multirow[t]{2}{*}{ Nilai Peserta Didik } & KELAS EKSPERIMEN & .163 & 17 & $.200^{\star}$ & .959 & 17 & .619 \\
\hline & KELAS KONTROL & .222 & 17 & .026 & .921 & 17 & .153 \\
\hline
\end{tabular}

Berdasarkan data pada tabel 5 di atas dari hasil uji normalitas diketahui bahwa nilai signifikansi post-test pada kelas eksperimen sebesar 0,200 dan pada kelas kontrol sebesar 0,026 sehingga dari hasil tersebut dapat diketahui bahwasanya hasil dari uji normalitas kelas eksperimen dan kontrol lebih besar dari 0,05 maka dapat diambil kesimpulan bahwasanya hasil uji normalitas data post-test pada kelas eksperimen dan kelas kontrol tersebut berdistribusi normal. Setelah melakukan uji normalitas langkah selanjutnya yaitu melakukan uji homogenitas dengan hasil sebagai berikut:

Tabel 6. Hasil homogenitas post-test

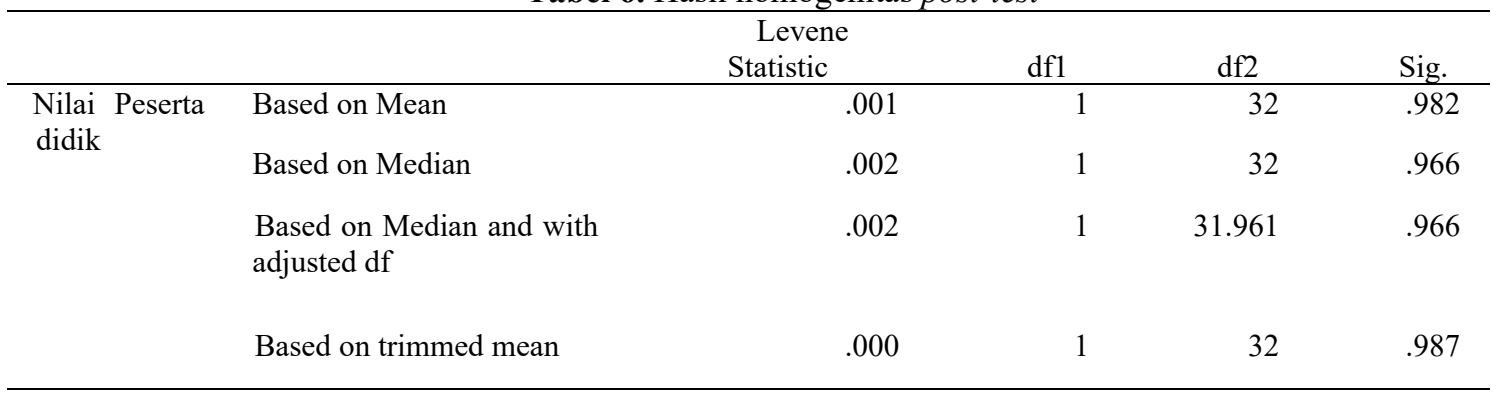

Berdasarkan data pada tabel 6 di atas dari hasil dari uji homogenitas dapat diketahui bahwa nilai signifikansi post-test pada kelas eksperimen dan kelas kontrol sebesar 0,982 Sehingga dapat diketahui bahwa nilai signifikansi kelas eksperimen dan kelas kontrol tersebut lebih besar dari 0,05 sehingga dapat diambil kesimpulan bahwa data post-test dari kedua kelas baik kelas eksperimen maupun kelas kontrol tersebut homogen.

Langkah selanjutnya setelah melakukan uji normalitas dan uji homogenitas melakukan uji hipotesis yang menggunakan uji one tailed sample test digunakan untuk mengetahui model pembelajaran problem based learning berbantuan media kahoot yang digunakan pada kelas eksperimen dan model pembelajaran konvensional atau ceramah yang digunakan untuk kelas kontrol didapatkan hasil sebagai berikut: 
Tabel 7. Hasil uji hipotesis post-test

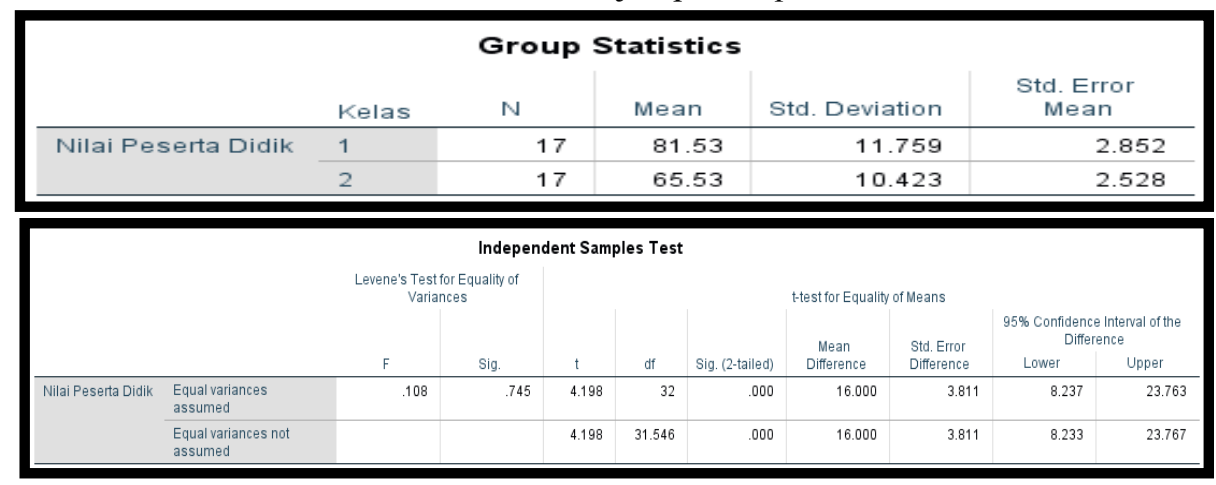

Berdasarkan hasil perhitungan pada tabel 7 menggunakan aplikasi SPSS di atas dapat disimpulkan bahwasanya diketahui p-value sebesar 0,000 sehingga karena p-value hasil perhitungan data tersebut kurang dari 0,05 maka Ho ditolak. Hal tersebut mengakibatkan kemampuan berpikir analitis antara kelas eksperimen maupun kelas kontrol setelah adanya perlakuan dengan menggunakan model pembelajaran problem based learning berbantuan media kahoot pada kelas eksperimen dan tanpa diberikan perlakuan apapun pada kelas kontrol dapat disimpulkan terdapat perbedaan yang signifikasi. Hal tersebut dikarenakan P-Value yang didapatkan kurang dari 0,05 . Sehingga untuk mengetahui lebih baik mana antara kemampuan berpikir analitis antara kelas eksperimen dan kelas kontrol lebih baik mana maka dapat dilihat dari mean (rata-rata). Rata-rata kemampuan berpikir analitis peserta didik kelas eksperimen sebesar 81,5 sedangkan kemampuan berpikir analitis pada kelas kontrol rata-rata kemampuan berpikir analitis peserta didik sebesar 63,5. Berdasarkan dari hasil tersebut dapat disimpulkan bahwa kemampuan berpikir analitis antara kelas eksperimen dan kelas kontrol lebih baik di kelas eksperimen.

Kemampuan berpikir secara analitis sangat dibutuhkan dan mempunyai peranan yang penting untuk peserta didik. Hakikatnya dalam kehidupan tidak lepas dari permasalahan sehingga kemampuan berpikir analitis ini sangat diperlukan untuk dapat memecahkan permasalahan yang terjadi, sehingga diperlukan sebuah kemampuan berpikir secara analitis untuk dapat mengambil sebuah keputusan yang terbaik. Hal tersebut perlu diketahui seseorang yang dapat menerapkan kemampuan berpikir secara analitis harus mampu mendefinisikan sebuah permasalahan terlebih dahulu sebelum mengolah sebuah informasi dan mencari solusi untuk menyelesaikan permasalahan tersebut.

Peserta didik harus mampu meningkatkan kemampuan berpikir secara analitis supaya peserta didik mampu menemukan solusi dalam menyelesaikan permasalahan yang disajikan, untuk itu model pembelajaran yang dapat diterapkan untuk meningkatkan kemampuan berpikir analitis ini yaitu dengan menggunakan model pembelajaran problem based learning. Penerapan model pembelajaran problem based learning ini dapat menyajikan sebuah permasalahan yang terbuka terkait dengan permasalahan lingkungan di sekitar sehingga dapat mengambil sebuah solusi dengan kemampuan berpikir secara analitis nya. penggunaan model pembelajaran problem based learning dapat melatih peserta didik untuk meningkatkan kemampuan berpikir analitis sehingga dapat mencapai tujuan pembelajaran yang dapat digunakan sebagai bekal untuk mampu menyelesaikan permasalahan yang sedang dihadapi.

Berdasarkan hasil dari penelitian yang dilakukan di MTs Ma'arif Al-Ishlah membuktikan bahwa model pembelajaran problem based learning berbantuan media kahoot ini dapat meningkatkan kemampuan berpikir analitis peserta didik di MTs Ma'arif Al-Ishlah. Hal tersebut dapat diketahui dari hasil statistika deskriptif bahwa nilai mean (rata-rata) kemampuan berpikir analitis peserta didik pada pre-test kelas eksperimen sebesar 55,00, sedangkan nilai mean (ratarata) pada nilai post-test sebesar 81,53. Kemudian pada kelas kontrol nilai mean (rata-rata) pre-

Jurnal Tadris IPA Indonesia Volume 1 Number 2, 2021 | p-ISSN 2776-3625 | e-ISSN 2776-3617 Copyright (C) 2021 Indah Eka Nurjanah, Edi Irawan, Rahmi Faradisya Ekapti, Ulinnuha Nur Faizah 
test sebesar 60,88, sedangkan nilai mean (rata-rata) nilai post-test sebesar 63,53, setelah dilakukan post-test terdapat peningkatan 26,53 pada kelas eksperimen dan terdapat peningkatan 2,65 pada kelas kontrol.

Hasil tersebut sesuai dengan penelitian yang dilakukan oleh Klaudius Ware dan Eli Rohaeti dalam penelitiannya didapatkan hasil bahwa model pembelajaran problem based learning dapat berpengaruh secara signifikan untuk meningkatkan kemampuan berpikir analitis dan keterampilan proses sains peserta didik SMAN 1 Sleman tentang materi penyangga. Hal tersebut dapat diketahui dari hasil uji hipotesis menggunakan uji ANAVA didapatkan hasil signifikansinya 0,000 . Karena hasilnya $0,000<0,05$ sehingga dapat disimpulkan bahwa model pembelajaran problem based learning dapat berpengaruh terhadap peningkatan kemampuan berpikir analitis dan keterampilan proses sains peserta didik kelas XI SMAN 1 Sleman pada materi larutan penyangga. Hal tersebut dikarenakan penggunaan model pembelajaran $P B L$ akan memberikan permasalahan kepada peserta didik sebelum melakukan pembelajaran dengan adanya pemberian masalah tersebut akan merangsang kemampuan berpikir peserta didik menjadi lebih baik.

Peningkatan tersebut signifikansi dengan berdasarkan hasil pengujian hipotesis dengan menggunakan uji one tailed sample test diperoleh nilai signifikansi nya adalah 0,000 sehingga karena $0,000<0,05$ sehingga kesimpulannya adalah $\mathrm{H}_{0}$ ditolak, karena $\mathrm{H}_{0}$ ditolak sehingga didapatkan hasil bahwa terdapat perbedaan yang signifikan antara penggunaan model pembelajaran problem based learning dengan penggunaan model pembelajaran konvensional atau ceramah apabila dilihat dari hasil uji one tailed sample test dan hasil uji mean atau rata-rata.

Pembelajaran IPA dalam penerapan kurikulum 2013 bersifat Integrative Science. Pembelajaran IPA dilaksanakan secara terintegrasi yang mempunyai makna bahwa pembelajaran IPA ini memadukan antara berbagai aspek baik itu aspek sikap, pengetahuan, dan juga aspek keterampilan. Pembelajaran IPA akan lebih bermakna apabila berorientasi pada aplikatif, pengembangan kemampuan berpikir, kemampuan belajar, rasa ingin tahu, dan pembangunan sikap peduli dan bertanggung jawab terhadap lingkungan alam dan sosial.

Penerapan model pembelajaran problem based learning berbantuan media kahoot tentunya memiliki kelebihan dan kelemahan. Penerapan model pembelajaran problem based learning berbantuan media kahoot apabila dihubungkan dengan pembelajaran dan pendidikan IPA mempunyai banyak sekali manfaatnya salah satunya yaitu dapat mengembangkan kemampuan berpikir tingkat tingginya khususnya kemampuan berpikir analitis peserta didik menjadi terlatih dan lebih baik lagi. Pembelajaran IPA hendaknya dirancang dan diimplementasikan melalui strategi yang dapat memenuhi kebutuhan kontekstual sehingga peserta didik dapat berhadapan dengan masalah nyata di lingkungannya untuk mendukung pembentukan pengetahuan, nilai, sikap, serta kemampuan berpikir tingkat tinggi yang terdiri dari critical thingking skill dan creative thingking khususnya kemampuan berpikir analisis. Adanya penelitian ini diharapkan model pembelajaran problrm based learning berbantuan media kahoot dapat digunakan untuk meningkatkan kemampuan berpikir tingkat tinggi peserta didik khususnya kemampuan berpikir secara analitis.

\section{KESIMPULAN}

Penggunaan model pembelajaran problem based learning berbantuan media kahoot efektif dalam meningkatkan kemampuan berpikir analitis peserta didik kelas VII di MTs Ma'arif Al-Ishlah mengenai tema pencemaran lingkungan. Hal ini dapat dilihat dari hasil uji hipotesis dengan menggunakan uji one tailed sample test menggunakan bantuan software SPSS diperoleh $P$-Value sebesar 0,000. kemampuan berpikir analitis peserta didik pada kelas eksperimen diperoleh mean (rata-rata) sebesar 81,5 sedangkan pada kelas kontrol diperoleh (mean) rata-rata sebesar 61,5. Model pembelajaran Problem Based Learning berbantuan media kahoot telah terbukti efektif dalam meningkatkan kemampuan berpikir secara analitis peserta didik, sehingga 
bisa menjadi salah satu alternatif model pembelajaran yang dapat meningkatkan kemampuan berpikir tingkat tinggi peserta didik salah satunya kemampuan berpikir secara analitis.

\section{REFERENSI}

Adi Adriadi and Nafan Tarihoran. (2016). Pembelajaran problem based learning (PBL) dan motivasi siswa terhadap hasil belajar PAI di SMP Negeri 1 Ciruas Serang. Jurnal Kajian Keislaman, 3(2), 15-37.

Afandi, M., Chamalah, E., \& Wardani, O. P. (2013). Model dan metode pembelajaran di sekolah. Perpustakaan Nasional Katalog Dalam Terbitan (KDT) (Vol. 392, Nomor 2). https://doi.org/10.1007/s00423-006-0143-4

Ahmadriswan nasution. (2020). Bahan ajar FSA angkatan ke-21 tahun 2020 Pengujian Hipotesis.

Astriani, D., Susilo, H., Suwono, H., \& Lukiati, B. (2018). Profil keterampilan berpikir analitis mahasiswa calon guru IPA dalam perkuliahan Biologi Umum. Jurnal Penelitian Pendidikan IPA, 2(2), 66. https://doi.org/10.26740/jppipa.v2n2.p66-70

Edi Irawan. (2014). Pengantar Statistika Penelitian Pendidikan (Aura Pustaka (ed.)).

Fitriyani, R., \& Duran Corebima, A. (2015). Pengaruh strategi pembelajaran problem based learning dan inkuiri terbimbing terhadap keterampilan metakognitif, berpikir kritis, dan hasil belajar kognitif siswa SMA. Jurnal Pendidikan Sains S3, 3(4), 186-200. http://journal.um.ac.id/index.php/jps/

Fitriani, F., Fadly, W., \& Faizah, U. N. (2021). Analisis Keterampilan Berpikir Analitis Siswa pada Tema Pewarisan Sifat. Jurnal Tadris IPA Indonesia, 1(1), 55-67.

Hasyim, F. (2018). Mengukur kemampuan berpikir analitis dan keterampilan proses sains mahasiswa calon guru fisika STKIP Al Hikmah Surabaya. JIPVA (Jurnal Pendidikan IPA Veteran), 2(1), 80. https://doi.org/10.31331/jipva.v2i1.591

Herawati, L. (2016). Uji normalitas data kesehatan menggunakan SPSS. Yogyakarta: Poltekkes Jogja Press.

Hidayati, A. R., Fadly, W., \& Ekapti, R. F. (2021). Analisis keterampilan berpikir kritis siswa pada pembelajaran IPA. Jurnal Tadris IPA Indonesia 1(1), 34-48.

Irawati, T. N., \& Mahmudah, M. (2018). Pengembangan instrumen kemampuan berpikir analisis siswa SMP dalam menyelesaikan soal pemecahan masalah matematika. Kadikma, 9(2), 111.

Kern, J. (1990). Implementation of new technology - The regulator's perspective. SAE Technical Papers, 7, 5-9. https://doi.org/10.4271/902340

Maghfiroh, U. (2011). Penerapan pembelajaran fisika bervisi sets untuk meningkatkan kemampuan berpikir analitis peserta didik kelas X. Jurnal Pendidikan Fisika Indonesia, 7(1), 6-12. https://doi.org/10.15294/jpfi.v7i1.1061

Noviani, Y., Hartono, \& Rusilowati, A. (2017). Analisis pola pikir siswa dalam menyelesaikan soal sains ditinjau dari kemampuan berpikir kritis dan kreatif serta literasi sains. Journal of Innovative Science Education, 6(2), 147-154.

Rahmawati, W., Ratnasari, J., \& Suhendar, S. (2018). Pengaruh pendekatan pembelajaran socioscientific issues terhadap kemampuan berpikir kreatif peserta didik. Jurnal Pelita Pendidikan, 6(2), 124-132. https://doi.org/10.24114/jpp.v6i2.10150

Risamasu, P. V. M. (2016). Pembelajaran IPA menumbuhkan karakter siswa. Prosiding Seminar Nasional PGSD UST, November, 249-259. https://doi.org/10.5281/zenodo.1039985

Rohmawati, E., Widodo, W., \& Agustini, R. (2018). Membangun kemampuan literasi sains siswa melalui pembelajaran berkonteks Socio-Scientific Issues berbantuan media Weblog. Jurnal Penelitian Pendidikan IPA, 3(1), 8. https://doi.org/10.26740/jppipa.v3n1.p8-14

Rusydi Ananda, M. F. (2018). Statistika Pendidikan: Teori dan Praktik dalam Pendidikan. Medan: CV Widya Puspita (Vol. 11, Nomor 3).

Widhy H, Purwanti, Sabar Nurohman dan Widodo Setyo Wibowo. (2013). Model integrated

Jurnal Tadris IPA Indonesia Volume 1 Number 2, 2021 | p-ISSN 2776-3625 | e-ISSN 2776-3617 Copyright (C) 2021 Indah Eka Nurjanah, Edi Irawan, Rahmi Faradisya Ekapti, Ulinnuha Nur Faizah 
science berbasis socio scientific issues untuk mengembangkan thinking skills dalam mewujudkan 21st century skills. Jurnal Pendidikan Matematika dan Sains, 1(2), 158-164. https://doi.org/10.21831/jpms.v1i2.2484

Sulastri, S., \& Pertiwi, F. N. (2020). Problem based learning model through constextual approach related with science problem solving ability of junior high school students. INSECTA: Integrative Science Education and Teaching Activity Journal, 1(1), 50. https://doi.org/10.21154/insecta.v1i1.2059

Yusri, A. Y. (2018). Pengaruh model pembelajaran problem based learning terhadap kemampuan pemecahan masalah matematika siswa kelas VII di SMP Negeri Pangkajene. Mosharafa: Jurnal Pendidikan Matematika, 7(1), 51-62. https://doi.org/10.31980/mosharafa.v7i1.341 